\title{
Retention Time in Three Nursery Container Volumes Impacts Root Architecture
}

\author{
Edward F. Gilman, Maria Paz, and Chris Harchick
}

\begin{abstract}
Roots descend and circle once they meet nursery container walls, sometimes resulting in severe defects. This has been attributed to extended retention time in small containers. Four retention times in 11 and $57 \mathrm{~L}$ containers were tested for their impact on root architecture inside finished $170 \mathrm{~L}$ containers. All taxa (Acer rubrum, Magnolia grandiflora, Ulmus parvifolia) retained for four months in $11 \mathrm{~L}$ containers required delicate handling to shift into $57 \mathrm{~L}$ containers because roots had not bound substrate together, making the shortest retention time (four months) impractical. Although shifting was easier for longer retention times (seven, nine, and twelve months), root system quality measured by root deflections declined with increasing retention time in 11 and $57 \mathrm{~L}$ containers. A greater percentage of the five largest roots grew down container walls than either circled or grew straight into substrate of 170 L containers. Nearly all the largest roots were deflected by the 11 or 57 L container with almost none reaching the $170 \mathrm{~L}$ container wall. Shorter retention time in 11 and $57 \mathrm{~L}$ containers was associated with a smaller percentage of trunks circled, more roots reaching the $170 \mathrm{~L}$ periphery, and for elm and magnolia, more trunk growth.

Key Words. Acer rubrum; Circling; Descending; Magnolia grandiflora; Nursery Production; Straight Roots; Ulmus parvifolia.
\end{abstract}

Trees and shrubs are easily shifted to larger containers once roots bind substrate together so the root ball remains intact when lifted from the container. Shifting too early can result in loss of substrate and possible root deformations as young, non-lignified roots become bent in the process. Retaining trees for a longer period of time allows roots deflected by container walls to become lignified and stiff in the deformed position. This can cause future stemgirdling roots, circling roots, descending roots, and other deformations that can impact health and anchorage (Burdett 1978; Balisky et al. 1995).

Dunn et al. (1997) and Salonius et al. (2000) showed a direct relationship between length of time tree seedlings were retained in propagation containers and the development of deformed root systems. Deformations in the root system can lead to poor rooting out, resulting in unstable trees (Lindgren and Örlander 1978). For example, Scots pine (Pinus sylvestris L.) trees planted from $75 \mathrm{ml}$ propagation containers developed spiraling (circling) roots, causing them to be less stable in the soil seven to nine years after planting than naturally regenerated trees (Lindström and Rune 1999). Many studies on conifer seedlings show that root deflection in propagation containers can contribute to long-term growth problems after planting in the forest (Krasowski 2003). Roots on shade trees in larger containers also deflect around or downward and proliferate at the bottom of containers (Marshall and Gilman 1998).

Balisky et al. (1995) provided evidence that root deformation occurred on trees growing in walled container systems before root density had increased sufficiently to facilitate normal extraction, handling, and transportation. Selby and Seaby (1982) found that seedlings of certain taxa develop lateral roots from the primary tap root in the first several weeks after seed germination. These authors attributed poor anchorage of out-planted pines to the lack of properly oriented lateral support roots and the inability of these seedlings to generate new lateral roots large enough after planting to support the tree. Permanent roots were formed in the first few weeks after seed germination and all were deflected by the 
container wall. For this reason, Lindström et al. (2005) tested a stabilized or reinforced substrate that could be easily removed from the container, intact, before all permanent roots were formed from the tap root and deflected by container walls. Stabilized substrates were developed to bind the root ball together to facilitate easy lifting and transfer to larger containers without loss of substrate. However, few trees are grown in this substrate (personal observation). In contrast, Coutts et al. (1990) found that some taxa are stabilized after planting by adventitious roots that develop after out-planting from propagation containers.

There is good evidence in the forestry (Salonius et al. 2000; Ortega et al. 2006) and horticulture (Harris et al. 1971; Marshall and Gilman 1998; Amoroso et al. 2010; Gilman et al. 2010a) literature that root architecture is more important than root mass to the health and anchorage of trees as they become established. Straight lateral roots radiating from the trunk are associated with well-anchored trees (Lindgren and Örlander 1978; Lindström and Rune 1999; Ortega et al. 2006; Gilman and Weise 2012). The objective of the present study was to determine impact of retention time in 11 and $57 \mathrm{~L}$ nursery containers on subsequent root architecture in the root ball on finished trees in $170 \mathrm{~L}$ containers. The taxa chosen for study were selected due to their popularity in many parts of temperate North America and elsewhere.

\section{MATERIALS AND METHODS}

In February 2007, 80 uniform rooted cutting liners of Magnolia grandiflora L. Miss Chloe ${ }^{\star}$ rooted in square $7.3 \mathrm{~cm}$ across $\times 14 \mathrm{~cm}$ deep smoothsided containers (Anderson Band AB39, Stuewe and Son, Inc., Tangent, Oregon, U.S.), and Acer rubrum L. 'Florida Flame' and Ulmus parvifolia Jacq. Allée rooted in circular $(5.1 \mathrm{~cm}$ top diameter, $13 \mathrm{~cm}$ tall ribbed containers, 38 Groovetube, Growing Systems, Inc., Milwaukee, Wisconsin, U.S.) propagation containers were potted into 11 L round, black, solid-walled nursery containers (Table 1). Magnolia roots originated primarily near the end of the cutting, whereas roots on maples and elms emerged near the end and from along the buried stem. The point where the topmost root emerged from stem was placed $13 \mathrm{~mm}$ below substrate surface by removing an appropriate amount of substrate from the top of liner root ball. This depth was found to be the ideal liner planting depth, for the one taxa tested (Gilman and Harchick 2008). The plot was located on woven black ground cloth in USDA hardiness zone $8 \mathrm{~b}$ (mean low temperature $-10^{\circ} \mathrm{C}$ ) in Gainesville, Florida, U.S.

Table 1. Retention time in 11, 57, and $170 \mathrm{~L}$ containers.

\begin{tabular}{llcc}
\hline & \multicolumn{3}{c}{ Container size $^{\mathrm{z}}(\mathrm{L})$} \\
\cline { 2 - 4 } Retention time & 11 & 57 & 170 \\
treatment & Retention time in container (months) \\
\hline A & 4 & 8 & 20 \\
$\mathrm{~B}$ & 7 & 10 & 15 \\
$\mathrm{C}$ & 9 & 11 & 12 \\
$\mathrm{D}$ & 12 & 14 & 6 \\
\hline${ }^{\mathrm{z}}$ Container dimensions as follows: $11 \mathrm{~L}=27 \mathrm{~cm}$ top diameter, $25 \mathrm{~cm}$ tall; \\
57 L = 44 cm top diameter, $38 \mathrm{~cm}$ tall; $170 \mathrm{~L}=75 \mathrm{~cm}$ top diameter, $48 \mathrm{~cm}$ \\
tall, round, solid-walled, black plastic containers (Nursery Supplies, Inc., \\
Chambersburg, Pennsylvania, U.S.).
\end{tabular}

Trees in $11 \mathrm{~L}$ containers were grouped by taxa and spaced pot-to-pot (i.e., touching one another) except for a $0.5 \mathrm{~m}$ walk row every four rows. Trees were irrigated two or three times daily, totaling $3.8 \mathrm{~L}$ through one Roberts (Roberts Irrigation Products, Inc. San Marcos, Idaho, U.S.) Spot-Spitter per container until autumn 2007 when irrigation frequency and volume was reduced for the dormant season. Trees in $11 \mathrm{~L}$ containers were randomly chosen for shifting into $57 \mathrm{~L}$ round, black, solid-walled nursery containers (Table 1); they were spaced $1.8 \mathrm{~m}$ apart and irrigated three times daily (weather dictating) in the growing season with a maximum of $15 \mathrm{~L}$ through two Roberts Spot-Spitters. Trees were shifted into $170 \mathrm{~L}$ round, black, solid-walled nursery containers (Table 1) in place, remaining $1.8 \mathrm{~m}$ apart. Irrigation occurred two to three times daily in the growing season, with a maximum of $45 \mathrm{~L}$ through three Roberts Spot-Spitters, until October 2009 when volume was dropped to $15 \mathrm{~L}$ daily or less frequently as weather dictated. Elm and maple shoots were pruned, and trunks staked, to develop one leader and to shorten and remove large lower branches, creating a $1.5 \mathrm{~m}$ trunk clear of branches to mimic standard practice. Magnolias were pruned only to maintain a central dominant leader. All trees were secured to a wire trellis system for stability in wind.

Trees were retained in 11 and $57 \mathrm{~L}$ containers before shifting to the larger size for four combinations of time (Table 1). Root balls were 
not pruned when shifted and were planted even with the substrate surface in the larger container. Total production time to reach marketable dimensions (Anonymous 2014) was 32 months for each set of four retention time treatments. Twenty magnolia and maple trees, and 12 elms (32 elms died from low winter temperature by June 2007) were randomly assigned to each treatment totaling 80 trees each for magnolia and maple, and 48 for elm.

Substrate was 50:40:10 (New Florida peat: pine bark: sand, by volume). New Florida peat is a compost of Florida peat and hardwood bark fines (Florida Potting Soil, Inc., Orlando, Florida, U.S.). Fertilizer (18-5-10 controlled release, Harrells Inc., Lakeland, Florida, U.S.) was incorporated into substrate prior to planting at $10.74 \mathrm{~kg} / \mathrm{m}^{3}$, and no other fertilizer was applied. Weeds were periodically pulled from container substrate. Excepting some elms, trees did not root out of pots and into ground.

Trunk diameter (15 cm from substrate) and tree height were measured at the end of each growing season in October 2007, 2008, and 2009. Root balls of the $170 \mathrm{~L}$ containers were too dense to wash substrate from the entire root ball. Therefore, the top $12 \mathrm{~cm}$ of each root ball was severed from the bottom using a mechanical saw blade cutting parallel to the substrate surface on five randomly chosen trees of each treatment and taxa in October 2009. Substrate was washed from the $12 \mathrm{~cm}$ thick disc to expose all roots, and many attributes were measured on the cut disc surface (see appropriate Table notes).

Taxa were arranged in their own randomized complete block design adjacent to one another once they were in $57 \mathrm{~L}$ containers; there were four treatments randomized in every block, with 20 (magnolia and maple) or 12 (elm) blocks. Blocks of $57 \mathrm{~L}$ containers were complete once the longest retention time in $11 \mathrm{~L}$ containers occurred (12 months). Analysis of variance (ANOVA) in the GLM procedure within SAS (SAS Institute, Cary, North Carolina, U.S.) was used to evaluate impact of the main effect (retention time) on measured parameters for each taxa independently. Tukey's multiple comparison test separated means at $P<0.05$.

\section{RESULTS}

Elms and magnolias retained four or seven months in $11 \mathrm{~L}$ containers had greater trunk diameter at the end of the study period, when trees were in $170 \mathrm{~L}$ containers, than those retained 12 months (Table 2). Maple response was opposite-those in $11 \mathrm{~L}$ containers four months were smaller than those retained 12 months. Magnolias in $11 \mathrm{~L}$ containers for four months were taller than trees retained longer; height trends for elms and maple were less clear.

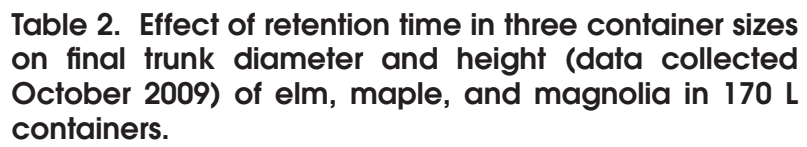
ontainers.

\begin{tabular}{lllll}
\hline \multicolumn{3}{c}{$\begin{array}{l}\text { Retention time (months) } \\
\text { in containers: }\end{array}$} & & \\
$11 \mathrm{~L}$ & $57 \mathrm{~L}$ & $170 \mathrm{~L}$ & Trunk diameter $(\mathrm{cm})$ & Height $(\mathrm{m})$ \\
\hline Elm & & & & \\
4 & 8 & 20 & $6.7 \mathrm{az}$ & $3.9 \mathrm{~b}$ \\
7 & 10 & 15 & $6.7 \mathrm{a}$ & $4.3 \mathrm{a}$ \\
9 & 12 & 11 & $6.4 \mathrm{a}$ & $4.5 \mathrm{a}$ \\
12 & 14 & 6 & $6.0 \mathrm{~b}$ & $4.2 \mathrm{ab}$ \\
& & & & \\
Maple & & & & $4.5 \mathrm{ab}$ \\
4 & 8 & 20 & $6.5 \mathrm{~b}$ & $4.7 \mathrm{a}$ \\
7 & 10 & 15 & $7.1 \mathrm{a}$ & $4.4 \mathrm{~b}$ \\
9 & 12 & 11 & $7.0 \mathrm{a}$ & $4.7 \mathrm{a}$ \\
12 & 14 & 6 & $6.9 \mathrm{a}$ & \\
& & & & $3.3 \mathrm{a}$ \\
Magnolia & & & $6.1 \mathrm{a}$ & $3.1 \mathrm{~b}$ \\
4 & 8 & 20 & $6.2 \mathrm{a}$ & $3.2 \mathrm{~b}$ \\
7 & 10 & 15 & $5.6 \mathrm{~b}$ & $3.1 \mathrm{~b}$ \\
9 & 12 & 11 & $5.1 \mathrm{~b}$ & \\
12 & 14 & 6 & &
\end{tabular}

Few trees of any taxa in $170 \mathrm{~L}$ containers were graded as culls according to Florida Grades and Standards for Nursery Plants (Anonymous 2015) at the end of the study period (Table 3 ). Roots circled less than $22 \%$ of the trunk circumference for all three taxa and retention times. Elm and maple retained the longest in the $11 \mathrm{~L}$ containers (treatment D) had a greater percentage of the trunk circled than trees retained four months. The number of elm roots $>5 \mathrm{~mm}$ diameter measured just inside the former position of the $11 \mathrm{~L}$ container was not impacted by retention time; however, the number of maple and magnolia roots was greater for trees retained in $11 \mathrm{~L}$ containers for 12 months than for four months. The number of roots inside the former position of the $57 \mathrm{~L}$ container decreased as 
retention time in small containers increased for elm but not for maple and magnolia. The number of roots $>5 \mathrm{~mm}$ diameter inside the $170 \mathrm{~L}$ container edge decreased with retention time in $11 \mathrm{~L}$ containers from seven to 12 months for all taxa. The number of roots $>5 \mathrm{~mm}$ diameter growing straight (radially from the trunk) to the $57 \mathrm{~L}$ container edge decreased with increasing $11 \mathrm{~L}$ retention time for elm, not for maple or magnolia. The number of magnolia roots that grew straight to the $170 \mathrm{~L}$ container edge increased as $11 \mathrm{~L}$ retention time decreased.

Mean diameter and total cross-sectional area (CSA) of maple roots ( $>5 \mathrm{~mm}$ diameter) inside the position of the $11 \mathrm{~L}$ container was larger for nine months retention time in $11 \mathrm{~L}$ containers than four; elm and magnolia were not affected (Table 4). Mean magnolia root diameter inside the position of the $57 \mathrm{~L}$ container was smaller with 12 months retention in $11 \mathrm{~L}$ containers compared to shorter retention times; total root CSA at 12 months was less than at four months. Mean elm and maple root diameter and CSA just inside $170 \mathrm{~L}$ container edge was larger with seven months retention than nine and 12 months retention time in 11 L containers; magnolia root CSA was larger for four months than nine and 12 months (Table 4).

The most common fate of the five largest roots was deflection downward (descending) by the 11 or $57 \mathrm{~L}$ containers for all retention times; circling and straight roots were significantly less common (Table 5). Retaining trees in $11 \mathrm{~L}$ containers only seven months compared to 12 resulted in a $50 \%$ or greater increase in straight roots for each taxa. A greater percentage of the five largest roots for all taxa were deflected by the 11 than by the $57 \mathrm{~L}$ container except elm retained four months (Table 6). The percentage of roots deflected by the $11 \mathrm{~L}$ container generally increased-and that in the $57 \mathrm{~L}$ container decreased-with $11 \mathrm{~L}$ retention time for elm and magnolia, but not for maple. Almost none of the five largest diameter roots were measured at the edge of the $170 \mathrm{~L}$ container (Table $6)$. The mean root diameter for five largest roots just inside the $170 \mathrm{~L}$ container generally decreased with increasing $11 \mathrm{~L}$ retention time for elm and maple, not magnolia (Figure 1).

Table 3. Effect of retention time in three container sizes on elm, maple, and magnolia root number in $170 \mathrm{~L}$ containers.

\begin{tabular}{|c|c|c|c|c|c|c|c|c|c|}
\hline \multirow{2}{*}{\multicolumn{3}{|c|}{$\begin{array}{l}\text { Retention time (months) } \\
\text { in containers: }\end{array}$}} & \multirow{3}{*}{$\begin{array}{l}\% \text { trunk circled } \\
\text { with roots }{ }^{z}\end{array}$} & \multirow{3}{*}{$\begin{array}{l}\% \text { cully } \\
\text { trees }\end{array}$} & \multicolumn{4}{|c|}{ No. of roots $>5 \mathrm{~mm}$ diameter } & \multirow{3}{*}{$\begin{array}{l}\text { Straight roots at } \\
170 \mathrm{~L} \text { container } \\
\text { edge }^{\mathrm{w}}\end{array}$} \\
\hline & & & & & \multirow[t]{2}{*}{$\begin{array}{l}\text { At position of } \\
11 \mathrm{~L} \text { container }\end{array}$} & \multirow[t]{2}{*}{$\begin{array}{l}\text { At position of } \\
57 \mathrm{~L}_{\text {container }}\end{array}$} & \multirow[t]{2}{*}{$\begin{array}{l}\text { At position of } \\
170 \mathrm{~L} \text { container }\end{array}$} & \multirow{2}{*}{$\begin{array}{l}\text { Straight roots at } \\
57 \mathrm{~L}_{\text {container }} \\
\text { edge }^{\mathrm{w}}\end{array}$} & \\
\hline $11 \mathrm{~L}$ & $57 \mathrm{~L}$ & $170 \mathrm{~L}$ & & & & & & & \\
\hline \multicolumn{10}{|l|}{ Elm } \\
\hline 4 & 8 & 20 & $8.8 c^{v}$ & 0 & 14.4 & $17.8 \mathrm{a}$ & $0.6 \mathrm{ab}$ & $6.6 \mathrm{a}$ & 0.6 \\
\hline 7 & 10 & 15 & $16.8 \mathrm{ab}$ & 20 & 16.8 & $15.4 \mathrm{a}$ & $1.2 \mathrm{a}$ & $6.2 \mathrm{a}$ & 0.8 \\
\hline 9 & 12 & 11 & $14.6 \mathrm{~b}$ & 0 & 15.8 & $7.8 \mathrm{~b}$ & $0.2 \mathrm{~b}$ & $4.0 \mathrm{ab}$ & 0.8 \\
\hline 12 & 14 & 6 & $21.6 \mathrm{a}$ & 0 & 15.8 & $6.6 \mathrm{~b}$ & $0 \mathrm{~b}$ & $3.2 \mathrm{~b}$ & 0 \\
\hline \multicolumn{10}{|c|}{ Maple } \\
\hline 4 & 8 & 20 & $8.7 \mathrm{~b}$ & 20 & $12.6 \mathrm{~b}$ & $16.6 \mathrm{~b}$ & $1.8 \mathrm{ab}$ & 5.4 & 1.4 \\
\hline 7 & 10 & 15 & $0 \mathrm{c}$ & 0 & $20.8 \mathrm{a}$ & $27.0 \mathrm{a}$ & $6.6 \mathrm{a}$ & 7.0 & 2.0 \\
\hline 9 & 12 & 11 & $12.1 \mathrm{ab}$ & 20 & $17.8 \mathrm{a}$ & $24.0 \mathrm{a}$ & $0.4 \mathrm{~b}$ & 4.6 & 0.6 \\
\hline 12 & 14 & 6 & $16.7 \mathrm{a}$ & 20 & $20.6 \mathrm{a}$ & $18.2 \mathrm{~b}$ & $0 \mathrm{~b}$ & 6.6 & 0.6 \\
\hline \multicolumn{10}{|c|}{ Magnolia } \\
\hline $4^{\circ}$ & 8 & 20 & 0 & 0 & $11.0 \mathrm{bc}$ & 26.6 & $13.6 \mathrm{a}$ & 9.4 & $3.2 \mathrm{ab}$ \\
\hline 7 & 10 & 15 & 4.4 & 0 & $9.8 \mathrm{c}$ & 20.6 & $11.0 \mathrm{a}$ & 10.4 & $4.4 \mathrm{a}$ \\
\hline 9 & 12 & 11 & 0 & 0 & $14.2 \mathrm{ab}$ & 24.6 & $6.6 \mathrm{~b}$ & 8.2 & $1.8 \mathrm{bc}$ \\
\hline 12 & 14 & 6 & 0 & 0 & $16.2 \mathrm{a}$ & 20.8 & $3.6 \mathrm{c}$ & 7.6 & $0.8 \mathrm{c}$ \\
\hline
\end{tabular}

${ }^{\mathrm{z}}$ Percent of circumference with root bark touching trunk bark.

y Percent of trees rated as cull based on root circling according to Florida Grades and Standards for Nursery Plants (Anonymous 2015).

${ }^{\mathrm{x}}$ Number of roots $>5 \mathrm{~mm}$ diameter one $\mathrm{cm}$ inside $11 \mathrm{~L}$ container position, between the 11 and $57 \mathrm{~L}$ position, and between the 57 and $170 \mathrm{~L}$ container position, respectively.

${ }^{w}$ Number of roots $>5 \mathrm{~mm}$ diameter that grew to the position of the 57 or $170 \mathrm{~L}$ container without turning more than 45 degrees left or right.

${ }^{v}$ Means in a column within species with a different letter are statistically different at $P<0.05 ; \mathrm{n}=5$. 
Table 4. Effect of retention time in three container sizes on root size of elm, maple, and magnolia in $170 \mathrm{~L}$ containers.

\begin{tabular}{|c|c|c|c|c|c|c|c|c|}
\hline \multirow{2}{*}{\multicolumn{3}{|c|}{$\begin{array}{l}\text { Retention time (months) } \\
\text { in containers: }\end{array}$}} & \multicolumn{3}{|c|}{ Mean diameter ${ }^{2}(\mathrm{~mm})$ roots $>5 \mathrm{~mm}$} & \multicolumn{3}{|c|}{ Total CSA $\left(\mathrm{mm}^{2}\right)$ roots $>5 \mathrm{~mm}$} \\
\hline & & & $\begin{array}{l}\text { At position of } \\
11 \mathrm{~L} \text { container }\end{array}$ & $\begin{array}{l}\text { At position of } \\
57 \mathrm{~L} \text { container }\end{array}$ & $\begin{array}{l}\text { At position of } \\
170 \mathrm{~L} \text { container }\end{array}$ & $\begin{array}{l}\text { At position of } \\
11 \mathrm{~L} \text { container }\end{array}$ & $\begin{array}{l}\text { At position of } \\
57 \mathrm{~L} \text { container }\end{array}$ & $\begin{array}{l}\text { At position of } \\
170 \mathrm{~L} \text { container }\end{array}$ \\
\hline \multicolumn{9}{|l|}{ Elm } \\
\hline 4 & 8 & 20 & 13.9 & 8.6 & $1.2 \mathrm{~b}^{\mathrm{y}}$ & 2647 & $1195 \mathrm{a}$ & $17 \mathrm{ab}$ \\
\hline 7 & 10 & 15 & 13.3 & 9.0 & $4.9 \mathrm{a}$ & 3160 & 1089 a & $41 \mathrm{a}$ \\
\hline 9 & 12 & 11 & 13.8 & 8.1 & $1.0 \mathrm{~b}$ & 3388 & $440 \mathrm{~b}$ & $4 \mathrm{~b}$ \\
\hline 12 & 14 & 6 & 12.7 & 7.8 & $0 \mathrm{~b}$ & 2557 & $349 \mathrm{~b}$ & $0 \mathrm{~b}$ \\
\hline \multicolumn{9}{|c|}{ Maple } \\
\hline 4 & 8 & 20 & $11.7 \mathrm{~b}$ & 9.6 & $4.6 \mathrm{ab}$ & $1891 \mathrm{~b}$ & $1427 \mathrm{~b}$ & $79 a b$ \\
\hline 7 & 10 & 15 & $12.0 \mathrm{~b}$ & 11.1 & $6.6 \mathrm{a}$ & $3027 \mathrm{ab}$ & 3179 a & $291 \mathrm{a}$ \\
\hline 9 & 12 & 11 & $15.9 \mathrm{a}$ & 9.0 & $1.5 \mathrm{bc}$ & 5018 a & $2019 a b$ & $19 \mathrm{~b}$ \\
\hline 12 & 14 & 6 & $14.2 \mathrm{ab}$ & 9.3 & $0 \mathrm{c}$ & $4219 a$ & $1513 \mathrm{~b}$ & $0 \mathrm{~b}$ \\
\hline \multicolumn{9}{|c|}{ Magnolia } \\
\hline 4 & 8 & 20 & 15.2 & $11.7 \mathrm{a}$ & 7.9 & 3033 & $3673 \mathrm{a}$ & 844 a \\
\hline 7 & 10 & 15 & 15.5 & $11.6 \mathrm{a}$ & 7.8 & 2831 & $2975 \mathrm{ab}$ & $513 \mathrm{ab}$ \\
\hline 9 & 12 & 11 & 15.0 & $11.1 \mathrm{a}$ & 7.5 & 3057 & $2971 \mathrm{ab}$ & 307 b \\
\hline 12 & 14 & 6 & 12.6 & $7.6 \mathrm{~b}$ & 6.6 & 2708 & $1068 \mathrm{~b}$ & $120 \mathrm{~b}$ \\
\hline
\end{tabular}

Table 5. Effect of retention time in three container sizes on elm, maple, and magnolia root architecture in $170 \mathrm{~L}$ containers.

\begin{tabular}{|c|c|c|c|c|c|}
\hline \multicolumn{3}{|c|}{$\begin{array}{l}\text { Retention time (months) } \\
\text { in containers }\end{array}$} & \multirow[t]{2}{*}{$\begin{array}{l}\text { Percent five largest roots circling } \\
\text { at position of } 11 \text { or } 57 \mathrm{~L} \text { container }{ }^{z}\end{array}$} & \multirow[t]{2}{*}{$\begin{array}{l}\text { Percent five largest roots descending } \\
\text { at position of } 11 \text { or } 57 \mathrm{~L} \text { container }{ }^{y}\end{array}$} & \multirow[t]{2}{*}{$\begin{array}{l}\text { Percent five largest roots straight at } \\
\text { position of } 11 \text { or } 57 \mathrm{~L} \text { container }\end{array}$} \\
\hline $11 \mathrm{~L}$ & $57 \mathrm{~L}$ & $170 \mathrm{~L}$ & & & \\
\hline \multicolumn{6}{|l|}{ Elm } \\
\hline 4 & 8 & 20 & $12 \mathrm{a}^{\mathrm{w}} \mathrm{B}^{\mathrm{v}}$ & $84 \mathrm{~A}$ & $4 \mathrm{cB}$ \\
\hline 7 & 10 & 15 & $12 \mathrm{aB}$ & $76 \mathrm{~A}$ & $12 \mathrm{aB}$ \\
\hline 9 & 12 & 11 & $8 \mathrm{bB}$ & $84 \mathrm{~A}$ & $8 \mathrm{bB}$ \\
\hline 12 & 14 & 6 & $4 \mathrm{cB}$ & $88 \mathrm{~A}$ & $8 \mathrm{bB}$ \\
\hline \multicolumn{6}{|c|}{ Maple } \\
\hline 4 & 8 & 20 & 20 & $44 c$ & $36 \mathrm{a}$ \\
\hline 7 & 10 & 15 & 20 & $40 \mathrm{c}$ & $40 \mathrm{a}$ \\
\hline 9 & 12 & 11 & $16 \mathrm{~B}$ & $84 \mathrm{aA}$ & $0 \mathrm{cB}$ \\
\hline 12 & 14 & 6 & 20 & $60 \mathrm{~b}$ & $20 \mathrm{~b}$ \\
\hline \multicolumn{6}{|c|}{ Magnolia } \\
\hline $4^{\circ}$ & 8 & 20 & $8 \mathrm{bB}$ & $80 \mathrm{aA}$ & $12 \mathrm{aB}$ \\
\hline 7 & 10 & 15 & $20 \mathrm{aB}$ & $68 \mathrm{bA}$ & $12 \mathrm{aB}$ \\
\hline 9 & 12 & 11 & $24 \mathrm{aB}$ & $68 \mathrm{bA}$ & $8 \mathrm{bB}$ \\
\hline 12 & 14 & 6 & $8 \mathrm{bB}$ & $84 \mathrm{aA}$ & $8 \mathrm{bB}$ \\
\hline
\end{tabular}

${ }^{\mathrm{z}}$ Percent of the five largest roots measured on cut root ball disc $12 \mathrm{~cm}$ below root ball top surface that circled at $<45$ degree angle relative to horizontal at either the 11 or $57 \mathrm{~L}$ container position.

${ }^{y}$ Percent of the five largest roots measured on cut root ball disc $12 \mathrm{~cm}$ below root ball top surface that descended relative to horizontal at $>45$ degree angle at either the 11 or $57 \mathrm{~L}$ container position.

${ }^{x}$ Percent of the five largest roots on cut root ball disc $12 \mathrm{~cm}$ below root ball top surface that grew without branching or deflecting at the 11 or $57 \mathrm{~L}$ container position, or if they branched the largest segment grew to the edge of the $170 \mathrm{~L}$ container without deflecting $>45$ degrees left or right.

${ }^{w}$ Means in a column within species with a different lower case letter are statistically different at $P<0.05 ; \mathrm{n}=5$.

${ }^{\mathrm{v}}$ Means in a row within species with a different upper case letter are statistically different at $P<0.05 ; \mathrm{n}=5$ using one way ANOVA for each retention time independently.

\section{DISCUSSION}

Trees of all taxa retained for four months in $11 \mathrm{~L}$ containers required delicate handling to shift to 57 L containers because roots had not bound substrate together. Roots were not stiff enough to remain in position when $11 \mathrm{~L}$ substrate fell from the root ball, resulting in some roots bending and re-orienting when placed into $57 \mathrm{~L}$ containers. For this reason, it would be impractical to recommend retaining these taxa in $11 \mathrm{~L}$ containers for only four months because a commercial operation (Pat Miller, Cherry Lake Tree Farm, Groveland, Florida, U.S.) would be unlikely to handle trees as carefully as required to keep root balls intact. Root balls were easier to handle when shifting from $11 \mathrm{~L}$ containers at seven months with less substrate loss; some roots (not measured) inevitably 
Table 6. Effect of retention time in three container sizes on deflected position of the five largest roots of elm, maple, and magnolia in 170 L containers.

\begin{tabular}{|c|c|c|c|c|c|}
\hline \multicolumn{3}{|c|}{$\begin{array}{l}\text { Retention time (months) } \\
\text { in containers }\end{array}$} & \multirow[t]{2}{*}{$\begin{array}{l}\% \text { roots deflected down or } \\
\text { around by } 11 \mathrm{~L} \text { container }\end{array}$} & \multirow[t]{2}{*}{$\begin{array}{l}\% \text { roots deflected down or } \\
\text { around by } 57 \mathrm{~L} \text { container }\end{array}$} & \multirow[t]{2}{*}{$\begin{array}{l}\% \text { roots deflected down or } \\
\text { around by } 170 \mathrm{~L} \text { container }\end{array}$} \\
\hline $11 \mathrm{~L}$ & $57 \mathrm{~L}$ & $170 \mathrm{~L}$ & & & \\
\hline \multicolumn{6}{|l|}{ Elm } \\
\hline 4 & 8 & 20 & $56 b^{y} A^{x}$ & $44 \mathrm{aA}$ & $0 \mathrm{~B}$ \\
\hline 7 & 10 & 15 & 64 bA & $32 \mathrm{bB}$ & $4 \mathrm{~B}$ \\
\hline 9 & 12 & 11 & $76 \mathrm{aA}$ & $24 \mathrm{cB}$ & $0 \mathrm{~B}$ \\
\hline 12 & 14 & 6 & $84 \mathrm{aA}$ & $16 \mathrm{~dB}$ & $0 \mathrm{~B}$ \\
\hline \multicolumn{6}{|c|}{ Maple } \\
\hline 4 & 8 & 20 & $80 \mathrm{aA}$ & $20 \mathrm{bB}$ & $0 \mathrm{C}$ \\
\hline 7 & 10 & 15 & 68 bA & $32 \mathrm{aB}$ & $0 \mathrm{~B}$ \\
\hline 9 & 12 & 11 & $76 \mathrm{abA}$ & $24 \mathrm{bB}$ & $0 \mathrm{~B}$ \\
\hline 12 & 14 & 6 & $80 \mathrm{aA}$ & $20 \mathrm{bB}$ & $0 \mathrm{~B}$ \\
\hline \multicolumn{6}{|c|}{ Magnolia } \\
\hline 4 & 8 & 20 & $72 \mathrm{bA}$ & $28 \mathrm{aB}$ & $0 \mathrm{C}$ \\
\hline 7 & 10 & 15 & $80 \mathrm{abA}$ & $20 \mathrm{bB}$ & $0 \mathrm{~B}$ \\
\hline 9 & 12 & 11 & $76 \mathrm{bA}$ & $24 \mathrm{abB}$ & $0 \mathrm{C}$ \\
\hline 12 & 14 & 6 & $88 \mathrm{aA}$ & $12 \mathrm{cB}$ & $0 \mathrm{~B}$ \\
\hline
\end{tabular}

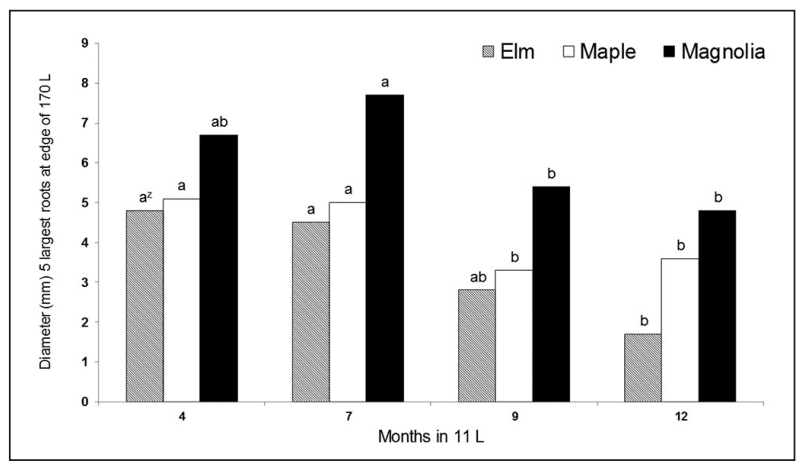

Figure 1. Mean diameter of five largest roots (measured 1 $\mathrm{cm}$ inside $170 \mathrm{~L}$ root ball periphery) with increasing retention time in $11 \mathrm{~L}$ container. ${ }^{2}$ Means within each species with a different letter are statistically different at $P<0.05$; $n=5$.

became re-orientated during shifting. Despite substrate and some root disturbance at four- and sevenmonth retention times in $11 \mathrm{~L}$ containers, trunk diameter growth was greater than for longer retention times for two of the three taxa tested (Table 2). Tree height in the four-month retention time (treatment A) was greater than (magnolia) or equal to (elm and maple) height in the 12 month treatment (treatment D). These results appear to support adoption of treatment $\mathrm{B}$, which includes a seven-month retention time in $11 \mathrm{~L}$ containers for maximizing trunk and crown growth rate. Growth appears to slow as the container substrate fills with deflected roots despite rigorous irrigation and fertilizer management.

Percent trunk circled with roots that touched trunk bark increased with retention time in 11 and
$57 \mathrm{~L}$ containers for elm and maple, not magnolia (Table 3). This was also found for the same maple (Gilman et al. 2012) and other tree taxa (Balisky et al. 1995; Salonius et al. 2000) in smaller propagation containers. However, there was no relationship between retention time and percent trees grading as a cull (the lowest grade, Anonymous 2015) for any taxa (Table 3). This could indicate that the longest retention times in 11 and $57 \mathrm{~L}$ containers (treatments C and D) were too short to induce circling root defects associated with some nursery trees. Trees in $170 \mathrm{~L}$ containers in this test were at least $2 \mathrm{~cm}$ less in trunk diameter than largest allowable in ANSI Z60 (Anonymous 2014), suggesting there are many trees with more developed root defects planted into landscapes. Future tests should grow trees to the largest standard size, or larger, for a given container, in order to test what could be a more typical condition.

An increase in the number of roots deflected at $11 \mathrm{~L}$ position with increasing $11 \mathrm{~L}$ retention time for two (maple and magnolia) of three taxa tested generally corresponded to fewer (Table 3 ) and smallerdiameter (Table 4) roots growing out into the top 12 $\mathrm{cm}$ of the larger container. This was demonstrated by the reduction in mean root diameter for elm and maple (measured one $\mathrm{cm}$ inside the $170 \mathrm{~L}$ container edge, Figure 1), and general reduction in root CSA between the 57 and 170 L containers (Table 4) with increasing $11 \mathrm{~L}$ retention time. The number of straight roots at 57 or $170 \mathrm{~L}$ container positions 
decreased with increasing retention time in the $11 \mathrm{~L}$; lack of straight roots has been associated with poor anchorage (Lindgren and Örlander 1978; Lindström and Rune 1999; Ortega et al. 2006; Gilman and Weise 2012). Essentially, the woody portion of the root system was deflected by and largely contained within 11 and $57 \mathrm{~L}$ container dimensions of the $170 \mathrm{~L}$ root ball (Table 6). Others also showed that deflected roots for maple (Gilman et al. 2012) and other taxa (Harris et al. 1971) continue to gain size in the deformed position, forming a root system imprint, and lateral roots growing from them were less abundant (Gilman and Paz 2014). Post-planting anchorage was reduced when woody roots were mostly deflected by the container instead of spreading out laterally (Gilman and Masters 2010; Gilman and Harchick 2014).

A much higher percentage of the five largest roots of all taxa grew down (descending) the container sidewall at the position of 11 or $57 \mathrm{~L}$ containers than either circled or grew straight into $170 \mathrm{~L}$ container substrate (Table 5). This tendency to deflect downward has been described for many taxa (e.g., Lindström and Rune 1999; Salonius et al. 2000). Presence of large roots deflected down or around has been associated with poor anchorage three years after planting Quercus virginiana Mill. from similar-sized containers and the same substrate as in the current study (Gilman and Masters 2010). The increase in percentage of five largest roots growing straight at seven- (treatment B) compared to twelve- (treatment $\mathrm{D}$ ) months retention time in $11 \mathrm{~L}$ containers for all taxa tested (Table 5) has been associated with higher-quality root systems in other taxa (Gilman and Weise 2012; Gilman and Harchick 2014).

Deflection of the largest five roots by the smaller containers (Table 6) indicated that roots produced in the first two years from stem cuttings remained the largest roots for the duration of the study period (3.5 years). Some roots initiated while trees were in 11 and $57 \mathrm{~L}$ containers for the shorter retention times may not have reached the container side when they were shifted to larger containers.
This likely explained increase in percentage of five largest roots growing straight into $170 \mathrm{~L}$ substrate with shorter retention time in the two smaller containers. Most permanent structural roots in treatments $\mathrm{C}$ and $\mathrm{D}$ (the longer retention times in the smaller containers) may have been initiated before trees were shifted to $170 \mathrm{~L}$ containers and therefore became deflected. Although new roots may have initiated from the root collar after shifting trees to $170 \mathrm{~L}$ containers, they were not the dominant roots in the end. Foresters have reported this on trees retained in much smaller (propagation) containers for long periods before planting (Burdett 1978; Chapman and Colombo 2006). The present study shows that roots deflected by 11 and $57 \mathrm{~L}$ containers can have a lasting impact on root architecture.

Shorter retention time in 11 and $57 \mathrm{~L}$ containers appears to be associated with more trunk growth (except maple, Table 2), a smaller percentage of trunk circled with roots (except magnolia), and more (Table 3) or larger (Table 4; Figure 1) roots reaching the $170 \mathrm{~L}$ periphery. However, great care was required to keep root balls intact at four- and seven-months retention times because roots had not sufficiently bound substrate together; perhaps a different substrate would respond in a different manner. Some defects resulted from roots drooping and becoming displaced and bent as substrate fell from the root ball during shifting. An alternative to short retention time includes allowing roots to grow sufficiently to bind substrate together. Deflected roots on the periphery can then be eliminated by root pruning (i.e., shaving, Weicherding et al. 2007; Gilman et al. 2010b; Gilman et al. 2012) or reduced in number by using certain container designs (Arnold and Young 1991; Chapman and Colombo 2006; Amoroso et al. 2010). This strategy may prove more effective or reliable than short retention times under certain growing conditions.

Acknowledgments. Thanks to innumerable Florida nursery operations and the Florida Nursery Growers and Landscape Association for contributing financial support for this project. 


\section{LITERATURE CITED}

Amoroso, G., P. Frangi, R. Piatti, F. Ferrini, A. Fini, and M. Faoro. 2010. Effect of container design on plant growth and root deformation of littleleaf linden and field elm. HortScience 45:18291829.

Anonymous. 2014. American Standard for Nursery Stock. ANSI Z60.1 American Nursery and Landscape Association, Washington, D.C., U.S.

Anonymous. 2015. Florida Grades and Standards for Nursery Plants. Florida Department of Agriculture and Consumer Services, Division of Plant Industry. <www.freshfromflorida.com/ pi/pubs.html>

Arnold, M.A., and E. Young. 1991. $\mathrm{CuCO}_{3}$-painted containers and root pruning affect apple and green ash root growth and cytokinin levels. HortScience 26:242-244.

Balisky, A.C., P. Salonius, C. Walli, and D. Brinkman. 1995. Seedling roots and forest floor: Misplaced and neglected aspects of British Columbia's reforestation effort? Forestry Chronicle 71:59-65.

Burdett, A.N. 1978. Control of root morphogenesis for improved stability in container-grown lodgepole pine. Canadian Journal of Forest Research 8:483-486.

Chapman, K.A., and S.J. Colombo. 2006. Early root morphology of jack pine seedlings grown in different types of container. Scandinavian Journal Forest Science 21:372-370.

Coutts, M.P., C. Walker, and A.C. Burnand. 1990. Effects of establishment method on root form of lodgepole pine and Sitka spruce and on the production of adventitious roots. Forestry 63:143-159.

Dunn, G.M., J.R. Huth, and M.J. Lewty. 1997. Coating nursery containers with copper carbonate improves root morphology of five native Australia tree species used in agroforestry systems. Agroforestry Systems 37:143-155.

Gilman, E.F., and C. Harchick. 2008. Planting depth in containers affects root form and tree quality. Journal of Environmental Horticulture 26:129-134.

Gilman, E.F., C. Harchick, and M. Paz. 2010a. Effect of container type on root form and growth of red maple. Journal of Environmental Horticulture 28:1-7.

Gilman, E.F., and C. Harchick. 2014. Container design influenced Swietenia mahogani root attributes and anchorage after landscape planting. Arboriculture \& Urban Forestry 40:27-35.

Gilman, E.F., and F. Masters. 2010. Effect of tree size, root pruning and production method on root growth and lateral stability of Quercus virginiana. Arboriculture \& Urban Forestry 36:281-291.

Gilman, E.F., and M. Paz. 2014. Root system morphology influenced by container design, retention time, and root pruning. Arboriculture \& Urban Forestry 40:16-25.

Gilman, E.F., M. Paz, and C. Harchick. 2010b. Root ball shaving improves root systems on seven tree species in containers. Journal of Environmental Horticulture 28:13-18.

Gilman, E.F., M. Paz, D. Meador, and P. Fisher. 2012. Propagation container type, time in container, and root pruning affect root development of young Acer rubrum. Journal Environmental Horticulture 30:150-160.

Gilman, E.F., and C. Wiese. 2012. Root pruning at planting and planting depth in the nursery impact root system morphology and anchorage. Arboriculture \& Urban Forestry 38:232-239.
Harris, R.W., W.B. Davis, N.W. Stice, and D. Long. 1971. Root pruning improves nursery tree quality. Journal American Society Horticulture Science 96:105-108.

Krasowski, M.J. 2003. Root system modifications by nursery culture reflect on post-planting growth and development of coniferous seedlings. Forestry Chronicle 79:882-891.

Lindgren O., and G. Örlander. 1978. A study on root development and stability of 6- to 7-year-old container plants. pp. 142-144. In: E. Van Eerden and J.M. Kinghorn (Eds.). Proceedings of the Root Form of Planted Trees Symposium, Victoria, B.C., Canada, May 16-19, 1978. Canadian Forest Service, B. C., Joint Report No. 8.

Lindström, A., and G. Rune. 1999. Root deformation in plantations of container-grown Scots pine trees: Effects on root growth, tree stability and stem straightness. Plant and Soil 217:29-37.

Lindström, A., C. Hellqvist, and E. Stattin. 2005. Mini Seedlings-A New Forest Regeneration System. pp. 56-58. In: The Thin Green Line: A symposium on the state-of-the-art in reforestation. Ontario Forest Research Institute, Ontario Ministry of Natural Resources, 1235 Queen Street East Sault Ste. Marie, Ontario, Canada P6A 2E5.

Marshall, M.D., and E.F. Gilman. 1998. Effects of nursery container type on root growth and landscape establishment of Acer rubrum L. Journal of Environmental Horticulture 16:55-59.

Ortega, U., J. Majada, A. Mena-Petite, J. Sanchez-Zabala, N. RodriguezItturrizar, K. Txarterina, J. Azpitarte, and M. Duñabeitia. 2006. Field performance of Pinus radiata D. Don produced in nursery with different types of containers. New Forests 31:97-112.

Salonius, P., K. Beaton, and B. Roze. 2000. Effects of cell size and spacing on root density and field performance of containerreared black spruce. Information Report M-X-208E, Canadian Forest Service, Atlantic Forestry Centre, Frederickton, New Brunswick, Canada.

Selby, C., and D.A. Seaby. 1982. The effect of auxins on Pinus contorta seedling root development. Forestry 55:125-135.

Weicherding, P.J., C.P. Giblin, J.H. Gillman, D.L. Hanson, and G. Johnson. 2007. Mechanical root-disruption practices and their effect on circling roots of pot-bound Tilia cordata Mill. and Salix alba L. 'Niobe'. Arboriculture \& Urban Forestry 33:43-47.

Edward F. Gilman (corresponding author)

Professor

Environmental Horticulture Department

University of Florida

Gainesville, Florida, U.S.

egilman@ufl.edu

Maria Paz

Biologist

Environmental Horticulture Department

University of Florida

Gainesville, Florida, U.S.

Chris Harchick

Farm Manager

Environmental Horticulture Department

University of Florida

Gainesville, Florida, U.S. 
Résumé. Dans un contenant de pépinière, les racines descendent dans le substrat et adoptent un développement circulaire lorsqu'elles atteignent les parois, conduisant parfois à de graves problèmes dans le futur. La période de rétention prolongée des jeunes plants dans de petits contenants en est la cause. Quatre types de périodes de rétention prolongées dans des contenants de $11 \mathrm{~L}$ et de $57 \mathrm{~L}$ furent été testés quant à leur impact sur l'architecture des racines une fois replantés dans les contenants de $170 \mathrm{~L}$. Tous les taxons (Acer rubrum, Magnolia grandiflora, Ulmus parvifolia) maintenus pendant quatre mois dans des contenants de $11 \mathrm{~L}$ ont ensuite été délicatement transférés dans des contenants de 57 $\mathrm{L}$ parce que les racines ne sétaient pas encore liées au substrat, il en a été par conséquent conclu que la période de rétention la plus courte, soit 4 mois, était irréalisable. Bien que la transplantation ait été plus facile pour les contenants des plus longues périodes de rétention (sept, neuf et douze mois), la qualité du système racinaire mesurée selon la quantité de déviations de racines diminuait avec l'augmentation du temps de rétention dans les contenants de $11 \mathrm{~L}$ et de $57 \mathrm{~L}$. Un plus grand pourcentage des cinq plus grosses racines se sont développées vers le bas des parois des contenants par rapport à celles qui ont poussé de manière circulaire le long des parois ou en sallongeant directement dans le substrat des contenants de $170 \mathrm{~L}$. Presque toutes les grosses racines ont été déviées par les parois des contenants de $11 \mathrm{~L}$ ou de $57 \mathrm{~L}$ mais presquaucune n'a atteint les parois des contenants de $170 \mathrm{~L}$. Une période de rétention plus courte dans les contenants de $11 \mathrm{~L}$ et de $57 \mathrm{~L}$ a été associée avec un plus faible pourcentage de racines encerclantes, davantage de racines atteignant la périphérie des contenants de $170 \mathrm{~L}$ et, chez l'orme et le magnolia, une plus importante croissance du tronc.

Zusammenfassung. Wurzeln wachsen nach unten und drehen sich, wenn sie den Boden des Pflanzcontainers erreicht haben, manchmal führt das zu ernsten Defekten. Das wird der langen Verweildauer in kleinen Pflanzcontainern geschuldet. Vier Verweilzeiten in 11 und 57 Liter Containern wurden auf ihren Einfluss auf die Wurzelarchitektur innerhalb eines 170 Liter Containers getestet. Alle Taxa (Acer rubrum, Magnolia grandiflora, Ulmus parvifolia), die für vier Monate in 11 Liter Containern blieben, erforderten einen sensiblen Umgang beim Umsetzen in einen 57 Liter Container, weil die Wurzeln das Substrat nicht zusammen hielten und dabei die kürzeste Verweildauer von vier Monaten unpraktisch machten. Obwohl die Umsetzung bei längeren Verweilzeiträumen (sieben, neun und zwölf Monate) leichter war, sank die Qualität des Wurzelsystems gemessen an der Wurzelbiegung mit zunehmender Verweildauer in 11 und 57 Liter Containern. Ein großer Prozentsatz von den fünf größten Wurzeln wuchs den Container hinunter und wuchs dann eintweder kreisförmig am Boden oder wuchs direkt in das Substrat des 170 Liter Containers. Fast alle großen Wurzeln wurden in den 11 oder 57 Liter Containern umgelenkt und fast keine erreichte die Wand des 170 Liter Containers. Kürzere Verweildauer in 11 und 57 Liter Containern war verbunden mit einem kleineren prozentualen Anteil von Ringwurzeln, mehr Wurzeln, die die 170 Liter Peripherie erreichten und bei Ulmen und Magnolien mit mehr Stammwachstum.

Resumen. Las raíces descienden y enrollan una vez que topan con las paredes del contenedor en el vivero, resultando algunas veces en defectos severos. Esto se ha atribuido al tiempo que ha permanecido en pequeños contenedores. Se probaron cuatro períodos de retención en contenedores de 11 y $57 \mathrm{~L}$ para probar su impacto en la arquitectura de las raíces, hasta terminar en contenedores de $170 \mathrm{~L}$. Todos los taxones (Acer rubrum, Magnolia grandiflora, Ulmus parvifolia) retenidos durante cuatro meses en contenedores de $11 \mathrm{~L}$ requirieron manejo delicado para cambiarlos a contenedores de $57 \mathrm{~L}$ porque las raíces no habían amarrado suficiente sustrato, haciendo impráctico el menor tiempo de retención (cuatro meses). Aunque el cambio era más fácil para tiempos más largos de reten- ción (siete, nueve y doce meses), la calidad del sistema de raíces medida por desviaciones de la raíz disminuyó con el aumento en el tiempo de retención en contenedores de 11 y 57 L. Un mayor porcentaje de cinco grandes raíces creció hacia abajo de las paredes del recipiente, que enrolladas en el sustrato de contenedores de $170 \mathrm{~L}$. Casi todas las raíces más grandes fueron desviadas por el recipiente 11 o 57 L y casi ninguna llegó a la pared del recipiente de 170 L. El menor tiempo de retención en contenedores de 11 y $57 \mathrm{~L}$ se asoció con un menor porcentaje de tallos enrollados, más raíces en la periferia de $170 \mathrm{~L}$, y para el olmo y la magnolia, mayor crecimiento del tronco. 